DOI: 10.34015/2523-4552.2019.1.08

удк 343.85

\author{
Михайлик О. Г., \\ кандидат юридичних наук, \\ докторант кафедри управління безпеки, \\ правоохоронної та антикорупційної \\ діяльності Міжрегіональної Академії \\ управління персоналом
}

\title{
ПОНЯТТЯ ТА СТРУКТУРА КРИМІНАЛЬНО-ПРАВОВОГО НАСИЛЬСТВА В УСТАНОВАХ ВИКОНАННЯ ПОКАРАНЬ
}

У статті наведено наукове й правове обгрунтування поняття та структури кримінально-правового насильства в установах виконання покарань. Сформульовано авторський підхід до структури кримінально-правового насильства в установах виконання покарань. Зокрема, в такій структурі запропоновано виділяти наступні групи злочинів: 1) насильницькі некорисливі злочини; 2) корисливі насильницькі злочини; 3) насильницькі злочини, що посягають на волю, честь і гідність особи, громадську безпеку, а також на авторитет органів державної влади; 4) насильницькі злочини, що посягають на правосуддя; 5) корупційні та інші злочини у сфері службової діяльності персоналу установ виконання покарань, а також з боку засуджених, яким властиві такі ознаки, як психологічне та економічне насильство по відношенню як до потерпілого, так і суб'єкта злочину.

Ключові слова: насильство; установа виконання покарань; кримінальноправове насильство; структура кримінально-правового насильства; засуджені; персонал.

В статье приведено научное и правовое обоснование понятия и структуры уголовно-правового насилия в учреждениях исполнения наказаний. Сформулирован авторский подход к структуре уголовно-правового насилия в учреждениях исполнения наказаний. В частности, в такой структуре предложено выделять следующие группы преступлений: 1) насильственные некорыстные преступления; 2) корыстные насильственные преступления; 3) насильственные преступления, посягающие на свободу, честь и достоинство личности, общественную безопасность, а также на авторитет органов государственной власти; 4) насильственные преступления, посягающие на правосудие; 5) коррупционные и иные преступления в сфере служебной деятельности персонала учреждений исполнения наказаний, а также со стороны осужденных, которым присущи такие признаки, как психологическое и экономическое насилие по отношению как к потерпевшему, так и субъекту преступления.

Ключевые слова: насилие; учреждение исполнения наказаний; уголовноправовое насилие; структура уголовно-правового насилия; осужденные; персонал.

(C) Михайлик О. Г., 2019

97 | С торінка 
Постановка проблеми. Сучасний стан функціонування установ виконання покарань характеризується низкою проблем, однією з яких $\epsilon$ неповне досягнення мети захисту інтересів особи, суспільства і держави, закріпленої в ч. 1 ст. 1 КВК України. Одним із криміногенних чинників, що зумовлює такий стан справ, $є$ насильство в системі установ виконання покарань (далі - УВП) Міністерства юстиції України. При цьому зазначеному явищу властивий дуалізм кримінально-виконавчих правовідносин, що проектується на кримінологічну сферу - можливість перебування як у ролі особи злочинця, так і жертви злочину обидвох суб'єктів - засуджених та персоналу УВП. При цьому одним із аспектів запобігання насильству в УВП (особливо в його найбільш небезпечній формі - кримінальноправовій) $\epsilon$ володіння спеціальними суб'єктами повною інформацією про його структуру з тим, щоб мати повну кримінально-правову і кримінологічну картину цього явища.

Аналіз останніх досліджень і публікацій. Теоретичною базою написання статті стали наукові праці вітчизняних і зарубіжних вчених, зокрема таких, як: Ю. М. Антоняна, М. П. Барабанова, В. С. Батиргареєвої, I. Г. Богатирьова, М. Г. Вербенського, П. А. Вороб'я, В. О. Глушкова, В. В. Голіни, Б. М. Головкіна, В. К. Грищука, О. М. Гуміна, I. М. Даньшина, С. Ф. Денисова, Т. А. Денисової, О. М. Джужі, А. І. Долгової, В. М. Дрьоміна, О. О. Дудорова, В. П. Ємельянова, А. П. Закалюка, А. Ф. Зелінського, О. Г. Кальмана, I. І. Карпеця, В. В. Коваленка, О. Г. Колба, I. М. Копотуна, О. М. Костенка, В. М. Кудрявцева, І. П. Лановенка, О. М. Литвака, О. М. Литвинова, В. В. Лунєєва, М. І. Мельника, В. А. Ми- сливого, П. П. Михайленка, С. С. Мірошниченка, А. А. Музики, Ю. В. Орла, В.І. Осадчого, М. С. Пузирьова, А. В.Савченка, О. В. Старкова, В. В. Сташиса, А. Х. Степанюка, В. Я. Тація, В. М. Трубникова, В. О. Тулякова, Г. А. Туманова, П. Л. Фріса, М. І. Хавронюка, В. Б. Шабанова, В. I. Шакуна, О. О. Шкути, В. Є. Южаніна, Н. М. Ярмиш, С. С. Яценка, М. М. Яцишина та інших дослідників.

Постановка завдання. Метою статі $\epsilon$ наукове й правове обгрунтування поняття та структури кримінально-правового насильства в УВП.

Виклад основного матеріалу. У межах цієї статті, розвиваючи наявний у сучасній українській кримінології широкий підхід щодо поділу насильницьких злочинів на три групи (некорисливі; корисливі; які посягають на основи національної або громадської безпеки, а також на авторитет органів державної влади і місцевого самоврядування [1, с. 246]), за результатами власного наукового пошуку сформульовано авторський підхід до структури кримінальноправового насильства в УВП. Зокрема, в такій структурі пропонуємо виділяти наступні групи злочинів.

\section{1. Насильницькі некорисливі} злочини. Це суто насильницькі злочини, про які зазначали В. М. Кудрявцев [2, с. 265-266] та В. В. Василевич [3, с. 82]. Якщо розглядати такі злочини як насильницькі без включення до відповідної групи інших злочинних посягань, в яких наявний насильницьких спосіб вчинення злочину, проти власності, інших родових об'єктів тощо, то справедливо говорити про вузьке розуміння кримінально-правового насильства. Ми не дотримуємося цього підходу, а розглядаємо насильство загалом та в УВП зокрема як комплексне явище, у ме- 
жах якого виділяється декілька родових об'єктів, а не лише життя та здоров'я особи.

Яскравий приклад насильницького некорисливого злочину в умовах УВП - просте умисне вбивство (ст. 115 Кримінального кодексу (далі - КК) України) або умисне тяжке тілесне ушкодження (ст. 121 КК України).

Варто погодитись із висловленою у кримінологічній науці позиці$є ю$, «о «насильницькі некорисливі злочини (суто насильницькі) кульмінацією мають безпосередньо насильство, вчинивши яке злочинець вважає, що досяг своєї мети. Мотивами цих злочинів можуть бути помста, ревнощі, заздрість, хуліганські спонукання, гіпертрофований статевий інстинкт, садистські нахили. Але завжди в основі механізму злочинної поведінки виявляється агресивнозневажливе, цинічне ставлення до особи, її життя, фізичного і психічного здоров'я, честі й гідності. Злочинне діяння може бути спрямоване як на конкретну особу, так і на невизначене коло осіб» [1, с. 246-247].

Зважаючи на викладене, до насильницьких некорисливих злочинів, які вчиняються в УВП, слід також віднести: погрозу вбивством (ст. 129 КК України), зґвалтування (ст. 152 КК України), сексуальне насильство (ст. 153 КК України). Проте із кримінологічної точки зору погрозу вбивством ми відносимо до психічного насильства, а зґвалтування та сексуальне насильство - до сексуального. Це пояснюється як особливостями формування механізмів злочинної поведінки, так і особливими факторами пенітенціарного мікросередовища, за яких вчиняються відповідні злочини.

\section{2. Корисливі насильницькі} злочини. Для цієї групи злочинів, яка, на відміну від попередньої, не $є$ такою численною в умовах УВП, характерною особливістю $є$ те, що насильство виступає засобом досягнення іншої (окрім задоволення низинних агресивних мотивів) мети - наприклад, здобуття певного блага. Класичними прикладами корисливих насильницьких злочинів $\epsilon$ такі, як: умисне вбивство 3 корисливих мотивів (п. 6 ч. 2 ст. 115 КК України), грабіж, поєднаний із насильством (ч. 2 ст. 186 КК України), розбій (ст. 187 КК України), вимагання (ст. 189 КК України), бандитизм (ст. 257 КК України). Особливість перелічених злочинів полягає в тому, що метою їх вчинення $\epsilon$ злочинне збагачення.

Стосовно УВП окремі з перелічених злочинів можуть вчинятися як у межах установ закритого й відкритого типів (вбивство з корисливих мотивів), а деякі можуть вчинятися засудженими, які відбувають покарання в межах адміністративно-територіальної одиниці дислокації установи відкритого типу (тобто ті 3 перелічених злочинів, вчинення яких можливе в умовах вільного суспільства в силу тимчасового перебування засудженого за межами установи).

Особливо в межах цієї групи (проте не в тісному зв'язку з корисливими мотивами) варто виділити злочин, передбачений п. 9 ч. 2 ст. 115 КК України - умисне вбивство 3 метою приховати інший злочин або полегшити його вчинення [4]. В такому випадку засуджений, вчиняючи умисне вбивство, може переслідувати не мету заволодіння майном іншого засудженого (корисливий мотив), а прагнути позбутися свідка у 
кримінальному провадженні (інша кримінально-протиправна мета).

3. Насильницькі злочини, що посягають на волю, честь $і$ гідність особи, громадську безпеку, а такожс на авторитет органів держсавної влади. Ми згрупували в цій категорії три родові об'єкти: а) волю, честь і гідність особи; б) громадську безпеку; в) авторитет органів державної влади. Водночас ми врахували те, що додатковими (як обов'язковими, так і факультативними) об'єктами відповідних злочинів можуть бути: життя, здоров'я, особиста (у т. ч. психічна) недоторканність особи, її воля, честь і гідність.

Ураховуючи специфіку функціонування УВП, до насильницьких злочинів у межах цієї групи ми відносимо:

- захоплення заручників (ст. 147 (349) КК України). Ураховуючи специфіку функціонування УВП, ми об'єднали ці два склади злочинів, розуміючи при цьому можливість наявності декількох категорій потерпілих, а саме: засуджених, представників влади, працівників правоохоронних органів, інших осіб;

- масові заворушення (ст. 294

КК України);

- хуліганство (ч. 3, 4 ст. 296

КК України);

- опір працівникові правоохоронного органу (ст. 342 КК України);

- погроза або насильство щодо працівника правоохоронного органу (ст. 345 КК України);

- посягання на життя працівника правоохоронного органу (ст. 348 КК України).

Як показує практика функціонування УВП України, всі з вищенаведених злочинів у різні роки функціонування кримінально-виконавчої системи мали місце з тими або іншими кількісними показниками.

Сучасні вчені-кримінологи, розглядаючи дану групу злочинів, проте в умовах вільного суспільства, справедливо наголошують на тому, що відповідні насильницькі злочини «<...> мають на меті через насильство змінити характер діяльності владних структур, примусити їх виконувати незаконні дії, державних службовців - перейти межі їх повноважень, водночас підриваючи авторитет зазначених структур» [1, с. 247].

Вважаємо, що подібний висновок справедливо застосовувати і по відношенню до насильницьких посягань, що загрожують авторитету кримінально-виконавчої системи загалом та нормальній діяльності установ виконання покарань щодо виправлення засуджених, зокрема.

Водночас, ураховуючи специфіку особливого родового об'єкта окремих пенітенціарних злочинів, вважаємо за доцільне виокремити наступну групу насильницьких злочинів, що вчиняються в УВП.

4. Насильницькі злочини, що посягають на правосуддя. До таких варто віднести такі суспільно небезпечні діяння, передбачені розділом XVIII КК України, як:

а) злісна непокора вимогам адміністрації установи виконання покарань (ст. 391 КК України). Хоча об'єктивна сторона цього злочину полягає у злісній непокорі законним вимогам адміністрації установи виконання покарань або іншій протидії адміністрації у законному здійсненні ïi функцій, i, з першого погляду, не містить ознак насильства, проте якщо врахувати специфіку функціонування УВП, то справедливо говорити про психологічне насильство з боку 
засудженого по відношенню до пенітенціарного персоналу. Тим більше, що злісна непокора може перерости в дії, пов'язані з фізичним насильством (наприклад, вчинення злочину, передбаченого ст. 392 КК України, у формі нападу на адміністрацію УВП);

б) дії, що дезорганізують роботу установ виконання покарань (ст. 392 КК України). Цей злочин відмічається двома «насильницькими» елементами об'єктивної сторони:

- тероризування засуджених, під яким слід розуміти застосування насильства або погрози застосування насильства з метою примусити їх відмовитись від сумлінного ставлення до праці, додержання правил режиму, а також вчинення таких же дій із помсти за виконання громадських обов'язків зі зміцнення дисципліни і порядку в установі виконання покарань. Тероризуванням слід вважати також глумління і знущання над засудженими для їх залякування і перешкоджання виконанню покарання;

- напад на адміністрацію установи виконання покарань - вчинення насильницьких дій (зв'язування, відібрання зброї, нанесення побоїв або тілесних ушкоджень, вбивство та ін.), а також погроза застосування насильства відносно представника адміністрації у зв'язку з його законною службовою діяльністю, при наявності реальних підстав побоювання негайного виконання цієї погрози [5];

в) втеча 3 місця позбавлення волі або з-під варти (ст. 393 КК України), а саме один з елементів об'єктивної сторони складу злочину, передбаченого ч. 2 цієї статті, - втеча, поєднана із застосуванням насильства чи погрозою його застосування. Так, як зазначають автори науковопрактичного коментаря КК України професори М. І. Мельник та М. I. Хавронюк, втеча із застосуванням насильства чи погрозою його застосування має місце, якщо насильство чи погроза його застосування виступали способами втечі. Під насильством слід розуміти здійснення фізичного впливу на потерпілого, який може полягати у нанесенні побоїв, катуванні, заподіянні легких чи середньої тяжкості тілесних ушкоджень. Під погрозою застосування насильства розуміється залякування потерпілого застосуванням фізичного насильства [6, с. 891].

Разом із тим, у якості наукової гіпотези, підтвердженої практикою й останніми тенденціями законотворчості (коли до КК України було запроваджено таку форму насильства, як економічне), вважаємо, що у практиці функціонування УВП з позицій кримінально-правового регулювання наявне економічне насильство, що виявляється у примусових (провокаційних, погрозливих) діях економічного (корисливого) характеру з боку адміністрації УВП по відношенню до засуджених, що виявляються у вчиненні низки корупційних та інших злочинів у сфері службової діяльності, котрі становлять наступну групу у структурі кримінальноправового насильства в УВП.

5. Корупційні та інші злочини у сфері службової діяльності персоналу УВП, а також з боку засуджених, яким властиві такі ознаки, як психологічне та економічне насильство по відношенню як до потерпілого, так і суб'єкта злочину. Формулюючи назву цієї групи злочинів, що входять до структури кримінально-правового насильства в УВП, ми зважали на співвідношення примітки до ст. 45 КК України, яка містить роз'яснення поняття «корупційні злочини», з по- 
ложеннями розділу XVII «Злочини у сфері службової діяльності та професійної діяльності, пов'язаної з наданням публічних послуг» Особливої частини КК України, який містить характеристику складів відповідних злочинів.

Ураховуючи практику діяльності органів і установ виконання покарань Міністерства юстиції України, а також органів досудового розслідування України, до злочинів цієї групи ми відносимо наступні:

- зловживання владою або службовим становищем (ст. 364 КК України);

- перевищення влади або службових повноважень працівником правоохоронного органу (ст. 365 КК України);

- прийняття пропозиції, обіцянки або одержання неправомірної вигоди службовою особою (ст. 368 КК України);

- пропозиція, обіцянка або надання неправомірної вигоди службовій особі (ст. 369 КК України);

- провокація підкупу (ст. 370 КК України).

Таким чином, можемо констатувати, що злочини цієї групи вчиняються в обстановці примусово-владного характеру діяльності персоналу УВП, злочинна поведінка якого в умовах дії імперативного методу правового регулювання кримінально-виконавчих правовідносин дає підстави відносити її до таких форм, як психологічне та економічне насильство.

Висновки. Отже, на підставі вищевикладеного вводимо до наукового обігу такі поняття, як «кримінально-правове насильство в УВП» i «структура кримінально-правового насильства в УВП». Щодо дефінування відповідних термінів зазначимо наступне:
- кримінально-правове насильство в УВП - це форма злочинної поведінки суб'єктів виконання (адміністрації УВП) та відбування (засуджених) покарань, що виявляється у формі фізичного, сексуального, психологічного, економічного насильства, і посягає на охоронювані законом про кримінальну відповідальність суспільні відносини в контексті забезпечення нормальної діяльності УВП щодо виправлення засуджених;

\section{- структура кримінально-} правового насильства в УВП - це комплексна кримінально-правова i кримінологічна категорія, що дає можливість на підставі норм закону про кримінальну відповідальність, кримінологічної теорії і практики (переважно функціонування УВП) якісно згрупувати склади насильницьких злочинів, що посягають на різні родові об'єкти, виходячи зі специфіки кримінально-виконавчих правовідносин. Окрім науково-теоретичної цінності, запропонована дефініція має i практичне значення, оскільки дає можливість: по-перше, упорядкувати статистичну діяльність органів i установ виконання покарань Міністерства юстиції України щодо узагальнення кількісно-якісних показників пенітенціарної злочинності, правильно виокремивши 3 усього емпіричного масиву групу «насильницькі злочини, що вчиняються в УВП»; по-друге, уніфікувати діяльність спеціальних суб'єктів запобіжної діяльності в УВП за напрямом протидії такому суспільно небезпечному явищу, як насильство, що за сучасних умов розвитку кримінальноправових та кримінально-виконавчих правовідносин виявляється у чотирьох формах - фізичне, сексуальне, психологічне, економічне. 


\section{Список використаних джерел}

1. Кримінологія. Підручник. Практикум / В. С. Ковальський, О. М. Костенко, Г. С. Семаков та ін. Київ : Юрінком Інтер, 2017. 344 с. $448 \mathrm{c.}$

2. Кудрявцев В. Н. Закон, поступок, ответственность. Москва : Наука, 1986.

3. Василевич В. Поняття кримінологічної характеристики насильницьких злочинів. Право України. 1997. № 12. С. 82-84.

4. Кримінальний кодекс України: Закон України від 05.04.2001 р. № 2341-III. Відомості Верховної Ради України. 2001. № 25-26. Ст. 131.

5. Про судову практику в справах про злочини, пов'язані 3 порушеннями режиму відбування покарання в місцях позбавлення волі: постанова Пленуму Верховного Суду України від 26.03.1993 p. № 2. URL: https://zakon.rada.gov.ua/laws/show/v0002700-93 (дата звернення: 21.04.2019).

6. Науково-практичний коментар Кримінального кодексу України / за ред. М. І. Мельника, М. І. Хавронюка. 3-тє вид., переробл. та доповн. Київ : Атіка, 2004. 1056 c.

\section{References}

1. Kovalskij, V. S., Kostenko, O. M., Semakov, G. S. (2017). Kriminologiya. Pidruchnik. Praktikum. Kiyiv: Yurinkom Inter [in Ukrainian].

2. Kudryavcev, V. N. (1986). Zakon, postupok, otvetstvennost. Moskva: Nauka [in Russian].

3. Vasilevich, V. (1997). Ponyattya kriminologichnoyi harakteristiki nasilnickih zlochiniv. Pravo Ukrayini. 12, 82-84 [in Ukrainian].

4. Kriminalnij kodeks Ukrayini: Zakon Ukrayini vid 05.04.2001 r. № 2341-III. Vidomosti Verhovnoyi Radi Ukrayini. 2001. N 25-26. St. 131 [in Ukrainian].

5. Pro sudovu praktiku $\mathrm{v}$ spravah pro zlochini, pov'yazani z porushennyami rezhimu vidbuvannya pokarannya $\mathrm{v}$ miscyah pozbavlennya voli: postanova Plenumu Verhovnogo Sudu Ukrayini vid 26.03.1993 r. № 2. URL: https://zakon.rada.gov.ua/ laws/show/v0002700-93 (data zvernennya: 21.04.2019) [in Ukrainian].

6. Melnik, M. I., Havronyuk, M. I. (Red.). (2004). Naukovo-praktichnij komentar Kriminalnogo kodeksu Ukrayini 3-tye vid., pererobl. ta dopovn. Kiyiv: Atika [in Ukrainian].

O. Mykhailyk, Ph.D in Law, candidate for Doctor of Law degree at Security Management, Law Enforcement and Anti-Corruption Activities Chair of Interregional Academy of Personnel Management

\section{Concept and structure of criminal-legal violence in penal institutions}

The article presents the scientific and legal substantiation of the concept and structure of criminal-legal violence in penal institutions. The author's approach is formulated for the structure of criminal-legal violence in penal institutions. In particular, in this structure, it is proposed to allocate the following groups of crimes: 1) violent unmercenary crimes; 2) mercenary violent crimes; 3) violent crimes that violate the will, honor and dignity of a person, public safety, as well as the authority of public authorities; 4) violent offenses against justice; 5) corruption and other crimes in the field of service activities of penitentiary personnel, as well 
as committing by convicts, that have such features as psychological and economic violence in relation to both the victim and the subject of a crime.

According to the results of the study, the following concepts were introduced into scientific circulation: «criminal-legal violence in penal institutions» and «structure of criminal-legal violence in penal institutions». Thus, criminal-legal violence in penal institutions is a form of criminal behavior of the subjects of execution (administration of penal institutions) and serving (convicts) punishments, which is manifested in the form of physical, sexual, psychological, economic violence, and infringes upon protected by the law on criminal liability social relations in the context of ensuring the normal functioning of penal institutions for the correction of convicts. In its turn, the structure of criminal-legal violence in penal institutions is a comprehensive criminal-law and criminological category, which enables, based on the norms of the law on criminal liability, criminological theory and practice (mainly the functioning of penal institutions), to group qualitatively the composition of violent crime, encroaching on various generic objects, based on the specifics of criminal-executive legal relations.

Keywords: violence; penal institution; criminal-legal violence; structure of criminal-legal violence; convicts, personnel.

Надійшла до редакції 25.04.2019 